\title{
$\alpha_{1}$ プロテアーゼインヒビターの好中球遊走能に与える影響
}

\author{
一一好中球りクルーメントに扣ける調節機序に関する考察—
}

\section{青 柴 和 徹*}

Effect of alpha-1-proteinase inhibitor on chemotaxis and chemokinesis of polymorphonuclear leukocytes: Its possible role in regulating PMN recruitment in humans

We examined the effects of alpha-1-proteinase inhibitor $\left(\alpha_{1}-\mathrm{Pi}\right)$ in physiological concentrations on polymorphonuclear leukocyte (PMN) migration in vitro using the multiple blind well assay system.

Alpha-1-proteinase inhibitor had both stimulatory and inhibitory effects on cell migration depending on its concentration. The inhibitor was active in 1) inducing directed locomotion (chemotaxis) in concentrations of $0.02,0.2 \mathrm{mg} / \mathrm{ml}$ and non-directed locomotion (chemokinesis) in concentrations of $0.02,0.2$ and $2 \mathrm{mg} / \mathrm{ml}$, with maximum potency in both cases at $0.2 \mathrm{mg} / \mathrm{ml}$ (corresponding to the normal alveolar surface level in the lung), but 2) inhibiting chemotactic responsiveness to known chemoattractants at 2 and 10 $\mathrm{mg} / \mathrm{ml}$ (corresponding to normal and inflammatory blood levels, respectively) in order of potency.

These results suggest that $\alpha_{1}-\mathrm{Pi}$ may play a unique role in regulating inflammatory processes especially in the lung, through its stimulatory and inhibitory effects depending on its concentration.

Kazutetsu Aoshiba*

key words : alpha-1-proteinase inhibitor, chemotaxis, chemokinesis, leukocyte migration, polymorphonuclear

leukocyte

血液中より組織内一の好中球浸潤は，炎症を特 徵づける基本的病態の一つである，好中球遊走因 子として, 細菌, 補体, 炎症細胞などに由来する種 種の化学伝達物質が知られているが1), 炎症部位 への好中球リクルーメントが生体内でいかに調 節，制御されているかについては不明である。

近年，好中球細胞膜に存在するセリンプロテア 一ゼの活性化が活性酸素産生, 内皮細胞への粘着 および遊走運動の発現に重要であること, さらに プロテアーゼインヒビターの処理により，これら 細胞機能が抑制されることが指摘されている が2 4), その生理学的意義は十分に理解されてい ない。

* Department of Medicine 1, Tokyo Women's Medical College 東京女子医科大学第一内科学教室
今回，筆者らは，生体内に広く存在するセリン プロテアーゼインヒビターである $\alpha_{1}$ プロテアー ゼインヒビター $\left(\alpha_{1}-\mathrm{Pi}\right)$ に注目し, 生体内に存在 する種々の濃度の $\alpha_{1}-\mathrm{Pi}$ により好中球遊走能がい かに影響を受けているかを検討した。ささらに，そ の成績に基づき， $\alpha_{1}-\mathrm{Pi}$ が炎症部位への好中球り クルーメントを調節することにより炎症過程を修 飾している可能性について考察した.

\section{方 法}

ヒト $\alpha_{1} \mathrm{Pi}$ (血清より抽出), ヒト recombinant C 5 a, N-formyl-methionyl-leucyl-phenylalanine (fMLP) ヒト recombinant tumor necrosis factor $\alpha$ (TNF $\alpha$ ), phorbol myristate acetate(PMA), L1-tosylamide-2-phenylethyl-chrolomethyl ketone (TPCK), N- $\alpha$-p-tosyl-1-lysine-chloromethyl ketone(TLCK), superoxide dismutase (SOD, ウシ 赤血球より抽出)は,いずれも Sigma 社(St. Louis, Mo)から購入した。

(1) $\alpha_{1}-\mathrm{Pi}$ 純度の検討

ヒト血清より抽出された市販 $\alpha_{1}-\mathrm{Pi}$ 製剂(Sigma 社)の純度を検定する目的で，その一部試料をカ ラムクロマトグラフィーにて分析した。すなわ ち，実験に使用した $\alpha_{1}-\mathrm{Pi}$ 試料を生食に溶解(10 $\mathrm{mg} / \mathrm{ml}$ ) したのち, $\mathrm{G} 2000 \mathrm{SWL}$ カラム $(7.6 \times 300$ $\mathrm{mm}) 2$ 本飞 充填し, $0.1 \mathrm{M} \mathrm{PBS}+0.25 \mathrm{M} \mathrm{NaCl}$ (pH 6.8) $1 \mathrm{ml} / \mathrm{min}$ で溶出した.

\section{（2）好中球分離}

健常者 6 人より採血(EDTA 添加)し，デキスト ラン(分子量 $5,000,000)$ 添加後室温にて45分間静 置し, 赤血球を除去したのちに, percoll discontinuous gradient にて静かに重層，10分間 $400 \mathrm{~g}$ に て遠沈して好中球分画を得た。好中球はアルブミ ン $(1 \mathrm{mg} / \mathrm{ml})$ を加えた HEPES 緩衝液に浮遊し, $2 \times 10^{6}$ 個 $/ \mathrm{m} l$ に調整後, 緩衝液のみ，または $\alpha_{1}-\mathrm{Pi}$ $(0.02,0.2,2,10 \mathrm{mg} / \mathrm{ml}), \operatorname{TPCK}(2,5,25,50$ $\mu \mathrm{M}), \operatorname{TLCK}(10,50,250,500 \mu \mathrm{M})$ と室温下に 
て30分間インキュベートした，インキュベート後 の好中球生存率は，トリパンブルー法で $95 \%$ 以上 であり，細胞膜破壊の指標となる細胞浮遊液上清 中 $\mathrm{LDH}$ 活性も上昇していないことを確認した。

（3）好中球遊走能の測定

好中球遊走能は48穴マイクロケモタキシスチャ ンバー(Neuroprobe $\left.{ }^{\circledR}\right) を$ 用い，Fall らの方法 ${ }^{5)}$ に 準じて行った。すなわち，チャンバーの上室 $(50$ $\mu l)$ にはプロテアーゼインヒビターで処理した好 中球浮遊液 $\left(2 \times 10^{6} / \mathrm{m} l\right)$, 下室 $(25 \mu l)$ には実験の目 的に応じて化学遊走物質あるいは $\alpha_{1}-\mathrm{Pi}$ を入れ， 両室をポリカルボネートフィルター(PVP-free, Neuroprobe $\left.{ }^{\circledR}\right)$ で境したあと， $37^{\circ} \mathrm{C} 5 \% \mathrm{CO}_{2}$ 下に 30 分間インキュベートを行った。フィルターを Diff Quick 液(国際試薬 ${ }^{\mathbb{B}}$ )にて固定染色したあ と，フィルター下面に遊走した細胞数を 1,000 倍 率のもと光顕下で 5 視野数光, その平均值を求め た。実験項目はつぎの二つにわけた。

(1) プロテアーゼインヒビターが，化学遊走物 質による chemotaxis に影響を与えるか.

チャンバーの上室には各種濃度の $\alpha_{1}-\mathrm{Pi}(0.02$, $0.2,2,10 \mathrm{mg} / \mathrm{ml}), \operatorname{TPCK}(2,5,25,50 \mu \mathrm{M})$, $\operatorname{TLCK}(10,50,250,500 \mu \mathrm{M})$ 溶液あるいはこれら インヒビターを添加しない溶液中に好中球を浮遊 させ，下室には化学遊走物質としてfMLP $\left(10^{-7} \mathrm{M}\right)$ ， $\mathrm{C} 5 \mathrm{a}\left(10^{-7} \mathrm{M}\right), \operatorname{TNF} \alpha(10 / \mathrm{m} l), \operatorname{PMA}\left(10^{-9} \mathrm{M}\right)$ を入 れた。プロテアーゼインヒビタ一の効果は，イン ヒビターを添加していない好中球遊走数に対する 比率 $(\%)$ として求めた.

(2) $\quad \alpha_{1}-\mathrm{Pi}$ 自体の好中球遊走作用

Checkerboard 法6)により $\alpha_{1}-\mathrm{Pi}$ が好中球に対 乙, $\operatorname{chemotaxis}\left(\alpha_{1}-\mathrm{Pi}\right.$ 濃度勾配に沿った方向性の ある運動)または chemokinesis(濃度勾配が存在し ないときの方向性を持たない運動)作用を示すか 否かについて検討した。すなわち，緩衝液のみま たは $\alpha_{1}-\mathrm{Pi}(0.02,0.2,2,10 \mathrm{mg} / \mathrm{ml})$ をチャンバ 一の上・下室に入れ，異なる濃度勾配を作製し， 遊走数を数えた，結果は，両室に $\alpha_{1}-\mathrm{Pi}$ を含まな いチャンバーの遊走数に対する比率 $(\%)$ として求 めた。

な拈，活性化好中球からスーパーオキサイドが 産生され， $\alpha_{1}-\mathrm{Pi}$ が酸化されることにより遊走能 が変化した可能性を否定するために，好中球浮遊 液に $\operatorname{SOD}(0.2 \mathrm{mg} / \mathrm{ml})$ を加えて上記と同様の実験

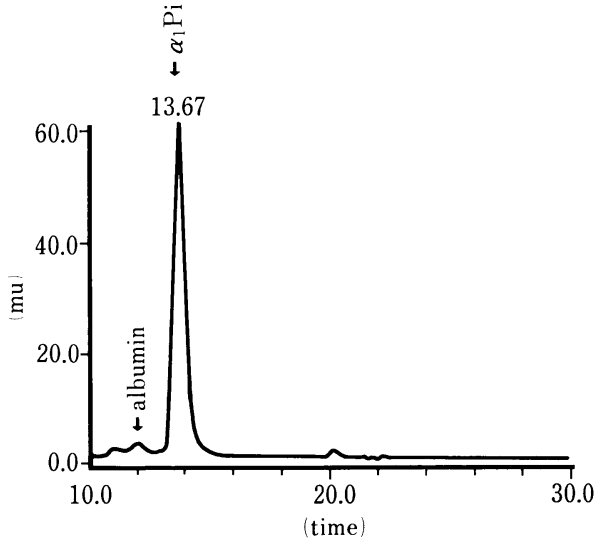

図 1 市販 $\alpha_{1}-\mathrm{Pi}$ 製剂(Sigma 社)の純度の検討 G 2000 SWL カラムクロマトグラフィーの結 果を示导。

を僧せて行った。

(4) 統計解析

結果は mean士SE としてあらわし，WilcoxonSigned-rank test で $\mathrm{P}<0.05$ を有意差ありとし た。

\section{結 果}

(1) $\alpha_{1}-\mathrm{Pi}$ 純度

カラムクロマトグラフィーにて市販の $\alpha_{1}-\mathrm{Pi}$ 製 剂中には $95 \%$ 以上の高純度で $\alpha_{1}-\mathrm{Pi}$ が含まれてい た(図 1 )。同剂中には $37 \mathrm{mg} / \mathrm{mg}$ の微量アルブミ ンが含まれていたが，最終的に $1 \mathrm{mg} / \mathrm{ml}$ のアル ジミンを加えた HEPES 液に溶解後実験に用いた ため，混入アルブミンが実験結果に及ぼす影響は 無視しらると考光られた。

（2）プロテアーゼインヒビターの化学遊走物質 による chemotaxis に対する影響

$\alpha_{1}-\mathrm{Pi}$ ，および合成プロテアーゼインヒビターで ある TPCK, TLCK は, $\mathrm{fMLP}\left(10^{-7} \mathrm{M}\right), \mathrm{C} 5 \mathrm{a}$ $\left(10^{-7} \mathrm{M}\right), \mathrm{TNF} \alpha(1 \mathrm{u} / \mathrm{ml})$ および $\operatorname{PMA}\left(10^{-9} \mathrm{M}\right) に$ よる chemotaxis を濃度依存性に抑制した(図 2 ). $\alpha_{1}-\mathrm{Pi}$ の場合, 各遊走物質による chemotaxis は, $2,10 \mathrm{mg} / \mathrm{ml}$ で濃度依存性に抑制されたが(抑制 率: $2 \mathrm{mg} / \mathrm{ml}, 41 \sim 61 \%$. $10 \mathrm{mg} / \mathrm{ml}, 44 \sim 91 \%$ ), $0.02,0.2 \mathrm{mg} / \mathrm{ml}$ では有意な変化は認められなか

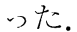

（3） $\alpha_{1}-\mathrm{Pi}$ 自体の好中球遊走活性

(1) chemokinesis : Checkerboard（表 1)に拈い て上下室濃度差のない $\mathrm{A}_{1 \sim 4}$ の遊走数は chemoki- 

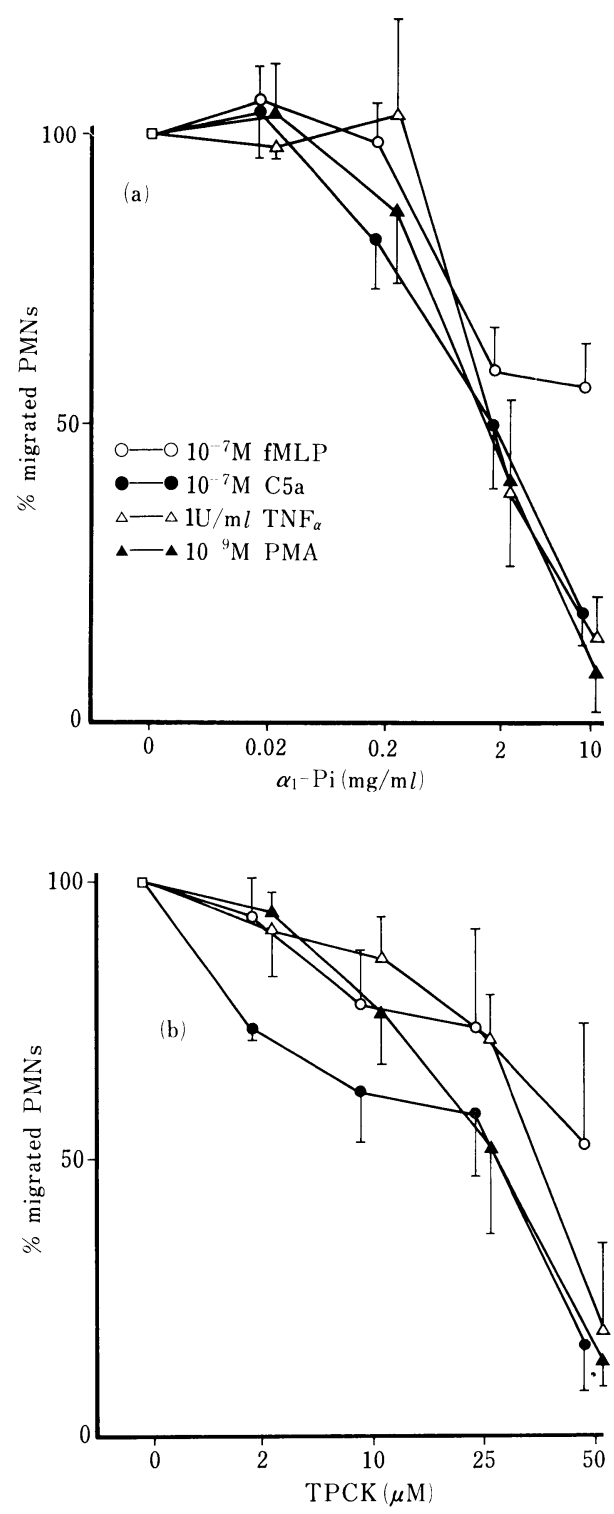

nesis をあらわしている. $\mathrm{A}_{1}(0.02 \mathrm{mg} / \mathrm{ml}), \mathrm{A}_{2}(0.2$ $\mathrm{mg} / \mathrm{ml}), \mathrm{A}_{3}(2 \mathrm{mg} / \mathrm{ml})$ の遊走数はコントロール A に比較して有意に増加して抢り，その程度は $\mathrm{A}_{2}>$ $\mathrm{A}_{1} \doteqdot \mathrm{A}_{3}$ であったことから，0.02，0.2, $2 \mathrm{mg} / \mathrm{ml}$ の $\alpha_{1}-\mathrm{Pi}$ は，好中球の chemokinesis を促進させ， その活性は $0.2 \mathrm{mg} / \mathrm{ml}$ に扔いてもっとも高度であ り, $0.02 \mathrm{mg} / \mathrm{ml}$ と $2 \mathrm{mg} / \mathrm{ml}$ ではほぼ同等である ことが知られた。一方， $\mathrm{A}_{4}$ の遊走数はコントロ ールと同様の值を示すことから, $10 \mathrm{mg} / \mathrm{ml}$ では chemokinesis 活性がないことが示された.

(2) chemotaxis：上下室間に 濃度勾配を有する チャンバーの遊走数は chemotaxis 活性を反映す

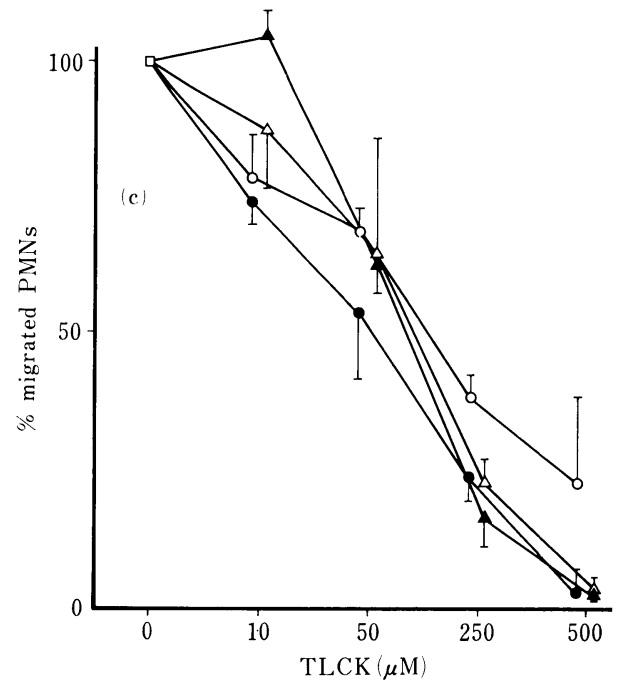

図 2 プロテアーゼインヒビターの化学遊走物 質による chemotaxis に対する影響

A : $\alpha_{1}-\mathrm{Pi} . \mathrm{B}:$ TPCK. C $:$ TLCK $\alpha_{1}-\mathrm{Pi}$ は, $2 \mathrm{mg} / \mathrm{ml}$ おょび $10 \mathrm{mg} / \mathrm{ml}$ では濃度 依存性に chemotaxis を抑制したが $(\mathrm{P}<0.05)$, $0.02 \mathrm{mg} / \mathrm{ml}$ および $0.2 \mathrm{mg} / \mathrm{ml}$ では変化を認 めなかった。

る、表における遊走数を比較すると $\mathrm{B}$ (上室 $0 \mathrm{mg}$ / $\mathrm{m} l$, 下室 $0.02 \mathrm{mg} / \mathrm{ml}$ ) は $\mathrm{B}^{\prime}$ (上室 $0.02 \mathrm{mg} / \mathrm{ml}$, 下 室 $0 \mathrm{mg} / \mathrm{ml}$ ) より高值を示し, 同様に $\mathrm{C}$ (上室 0 $\mathrm{mg} / \mathrm{ml}$, 下室 $0.2 \mathrm{mg} / \mathrm{ml}$ ) は $\mathrm{C}^{\prime}$ (上室 $0.2 \mathrm{mg} / \mathrm{ml}$, 下室 $0 \mathrm{mg} / \mathrm{ml}$ ) より高值であることから，0.02， $0.2 \mathrm{mg} / \mathrm{ml}$ の $\alpha_{1}-\mathrm{Pi}$ には chemotaxis 活性のある ことが知られた。ささらに, $\mathrm{F}$ (上室 $0.02 \mathrm{mg} / \mathrm{ml}$, 下 室 $0.2 \mathrm{mg} / \mathrm{ml}$ ) は $\mathrm{F}^{\prime}$ (上室 $0.2 \mathrm{mg} / \mathrm{ml}$, 下室 0.02 $\mathrm{mg} / \mathrm{m} l$ ) に比して高值を示した. chemokinesis 活性 は $0.02 \mathrm{mg} / \mathrm{ml}$ よりも $0.2 \mathrm{mg} / \mathrm{ml}$ の法らが高度 であることから，上記 $F>F^{\prime}$ の結果は chemokinesis 活性の差に基づくものではなく， chemotaxis 活性 が $0.02 \mathrm{mg} / \mathrm{ml}$ に比し, $0.2 \mathrm{mg} / \mathrm{ml}$ により強いこ とを示唆している。

一方, $\mathrm{D}$ (上室 $0 \mathrm{mg} / \mathrm{ml}$, 下室 $2 \mathrm{mg} / \mathrm{ml}$ ), $\mathrm{D}^{\prime}$ (上 室 $2 \mathrm{mg} / \mathrm{ml}$, 下室 $0 \mathrm{mg} / \mathrm{m} l$ ) 間, および $\mathrm{E}$ (上室 0 $\mathrm{mg} / \mathrm{ml}, 10 \mathrm{mg} / \mathrm{ml}$ ) , $\mathrm{E}^{\prime}$ (上室 $10 \mathrm{mg} / \mathrm{ml}$, 下室 $0 \mathrm{mg} /$ $\mathrm{m} l$ ) 間の遊走数には差がないことから，2および $10 \mathrm{mg} / \mathrm{ml}$ では chemotaxis 活性がないことが知ら れた。

以上の結果は，SOD にて処理した好中球にお いても，同様であった。

チャンバーの下室に $0.2 \mathrm{mg} / \mathrm{ml} \alpha_{1}-\mathrm{Pi}$ たは $10^{-7} \mathrm{M}$ fMLP を入れた際の遊走細胞数の絶対值 
表 $1 \alpha_{1}-\mathrm{Pi}$ 自体の好中球遊走活性の検討(Checkerboard 法)

\begin{tabular}{|c|c|c|c|c|c|c|}
\hline & & \multicolumn{3}{|c|}{ upper well $(\mathrm{mg} / \mathrm{ml})$} & & \multirow[b]{2}{*}{10} \\
\hline \multirow{4}{*}{ 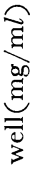 } & & 0 (buffer) & 0.02 & 0.2 & 2 & \\
\hline & 0 (buffer) & $100^{\mathrm{A}}$ & $135 \pm 19^{B^{\prime}}$ & $183 \pm 40^{\mathrm{C}^{\prime}}$ & $112 \pm 40^{\prime}$ & $68 \pm 20^{\mathrm{E}^{\prime}}$ \\
\hline & 0.02 & $216 \pm 40^{\mathrm{B}}$ & $251 \pm 65^{A_{1}}$ & $333 \pm 97 \mathrm{~F}^{\prime}$ & $237 \pm 47 \mathrm{E}^{\prime}$ & $158 \pm 59$ \\
\hline & 0.2 & $787 \pm 280^{\mathrm{C}}$ & $948 \pm 291^{F}$ & $977 \pm 288 \mathrm{~A}_{2}$ & $878 \pm 277$ & $792 \pm 227$ \\
\hline \multirow{2}{*}{$\begin{array}{l}\dot{0} \\
\vdots \\
0\end{array}$} & 2 & $195 \pm 45^{D}$ & $253 \pm 64$ & $294 \pm 56$ & $222 \pm 33 \mathrm{~A}_{3}$ & $190 \pm 55$ \\
\hline & 10 & $83 \pm 28^{\mathrm{E}}$ & $119 \pm 38$ & $159 \pm 42$ & $143 \pm 37$ & $125 \pm 51_{4}^{A_{4}}$ \\
\hline
\end{tabular}

$\mathrm{P}<0.05: \mathrm{A}$ vs $\mathrm{A}_{1 \sim 3}, \mathrm{~B}$ vs $\mathrm{B}^{\prime}, \mathrm{C}$ vs $\mathrm{C}^{\prime}, \mathrm{F}$ vs $\mathrm{F}^{\prime}$ not significant: $\mathrm{A}$ vs $\mathrm{A}_{4}, \mathrm{D}$ vs $\mathrm{D}^{\prime}, \mathrm{E}$ vs $\mathrm{E}^{\prime}$

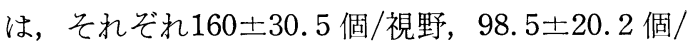
視野 $(\mathrm{P}<0.05)$ であり, $0.2 \mathrm{mg} / \mathrm{ml} \alpha_{1}-\mathrm{Pi}$ の chemotaxis 活性は $10^{-7} \mathrm{M} \mathrm{fMLP}$ のそれを上回るものと 考えられた。

\section{考 察}

$\alpha_{1}-\mathrm{Pi}$ は, $0.02 \sim 10 \mathrm{mg} / \mathrm{ml}$ の範囲において 濃 度に応じて好中球遊走能に異なった影響を与える ことが示された。すなわち，低濃度域では chemokinesis $(0.02,0.2,2 \mathrm{mg} / \mathrm{ml})$ \& chemotaxis $(0.02,0.2 \mathrm{mg} / \mathrm{ml})$ を誘導し，その活性はともに $0.2 \mathrm{mg} / \mathrm{ml}$ に抢いて最大であった。一方，高濃 度域 $(2,10 \mathrm{mg} / \mathrm{m} l)$ に扔いては, 濃度依存性に化 学遊走物質による好中球 chemotaxis を抑制した。

高濃度域の $\alpha_{1}-\mathrm{Pi}$ による chemotaxis 抑制作用 については，合成プロテアーゼインヒビターであ る TPCK, TLCK でも同様に抑制したことから， その抗プロテアーゼ活性が関与しているものと考 えられる. 非特異的な細胞障害による可能性も考 えられるが，好中球を最大濃度 $(10 \mathrm{mg} / \mathrm{ml})$ の $\alpha_{1}$ $\mathrm{Pi}$ でインキュベートしたあともトリパンブルー による生存率および細胞上清 LDH 活性に変化が ないことから，否定的である。

一方，抗プロテアーゼ活性の失われた酸化型， あるいはェラスターゼ結合型の $\alpha_{1}-\mathrm{Pi}$ に chemokinesis, chemotaxis 活性のあることが知られてい $\Xi^{7,8)}$. したがって, 筆者らの研究でみられた低濃 度域の $\alpha_{1}-\mathrm{Pi}$ による好中球遊走能活性化の機序に は，抗プロテアーゼ活性の関与は少ないと考光ら れる。

本研究の成績は, 従来の報告と一部異なってい る。従来の報告は, 筆者らの用いた $\alpha_{1}-\mathrm{Pi}$ 濃度に 比しょり低濃度について検討したものであるが，
本研究で示されたごとく $\alpha_{1}-\mathrm{Pi}$ は濃度に応じて異 なる作用を有することから，成績の相違点の解釈 には, 用いられた濃度差の影響を考慮する必要が ある。

Goetzl ${ }^{4)}$ および Stockley?) らは，それぞれ 0.001 $\mathrm{mg} / \mathrm{ml}, 0.002 \mathrm{mg} / \mathrm{ml}$ の低濃度で好中球の chemotaxis を抑制したと報告しているが，筆者の研究 では, その10倍から 100 倍に相当する $0.02 \mathrm{mg} / \mathrm{ml}$, $0.2 \mathrm{mg} / \mathrm{ml}$ 飞扔いてもその抑制作用が認められな かった。その理由としては，0.02 および $0.2 \mathrm{mg} /$ $\mathrm{m} l$ は好中球遊走能 (chemotaxis と chemokinesis) に対する刺激濃度であることから，たとえ同濃度 に化学遊走物質に対する chemotaxis 抑制作用が あったとしても，同時に chemokinesis 作用をも誘 導するため 好中球運動を六進させ，結果として $\alpha_{1}-\mathrm{Pi}$ の持つ抑制作用が 打ち消された可能性が考 えられる。

Hakansson ら ${ }^{9)}$ および Goetz14) は, 本研究の結 果と同様に，それぞれ $0.2 \mathrm{mg} / \mathrm{ml}$ のみ，または $0.1 \mathrm{mg} / \mathrm{ml}$ 以下の濃度範囲飞执いて chemokinesis を生じさせると述べている。しかし，これらの研 究ではさらに高い血中に相当する $\alpha_{1}-\mathrm{Pi}$ 濃度での 検討はなされていない。

一方, Ganda ら ${ }^{8)}$ 抢よび Stockely $5^{7)}$ は, 本研 究の結果と異なり， $\alpha_{1}-\mathrm{Pi}$ には chemoaxis や chemokinesis 活性は認められないとしている。乙 かし，彼らが検討した濃度は， $3 \times 10^{-6} \mathrm{mg} / \mathrm{ml}$ お よび $5 \times 10^{-6} \sim 5 \times 10^{-3} \mathrm{mg} / \mathrm{m} l$ と本研究での濃度 に比してきわめて低く，遊走刺激濃度に達してい ないことが推察される。

$0.02 \sim 10 \mathrm{mg} / \mathrm{ml}$ の濃度域において $\alpha_{1}-\mathrm{Pi}$ が好 中球遊走能飞対して低濃度では刺激性, 高濃度で は抑制性の二相性の作用を有することは炎症部位 
への好中球リクルーメントの調節機序を考えるら えで興味深い。本研究で検討した $\alpha_{1}-\mathrm{Pi}$ 濃度を生 体内濃度と対比させると, $0.2 \mathrm{mg} / \mathrm{ml}$ は正常肺胞 液(alveolar surfacelayer fluid) ${ }^{10)}, 2 \mathrm{mg} / \mathrm{ml}$ は正 常血液, $10 \mathrm{mg} / \mathrm{ml}$ は炎症時に増加した血液中濃 度に相当している。

肺胞液中の $0.2 \mathrm{mg} / \mathrm{ml}$ の $\alpha_{1}-\mathrm{Pi}$ は高度の chemotaxis, chemokinesis 活性を有する濃度である。

したがって, 本濃度に拈いては, 肺血管内から肺胞 内への好中球遊出を促進し, さらに肺胞腔内での 遊走を六進させ, 細菌などの外敵に対する防御能 として合目的な作用を有している可能性がある.

一方, 血中の $2 \mathrm{mg} / \mathrm{m} l$ の $\alpha_{1}-\mathrm{Pi}$ は chemotaxis を 抑制する濃度であることから，逆に好中球の血管 外遊走を抑止していると考它られる。

以上のように, 血液, 肺胞液中の $\alpha_{1}-\mathrm{Pi}$ 濃度差 に基づいた遊走能に対する相反する作用が正常時 に打ける肺胞内への好中球リクルーメントの調節 に関与している可能性が考劣られる。

一方，細菌感染などによりもたらされた肺内炎 症部位では，血管透過性の亢進により， $\alpha_{1}-\mathrm{Pi} の$ 肺胞液濃度は血中濃度に近づくと予想される。 し たがって, 炎症時には, 肺胞液中 $\alpha_{1}-\mathrm{Pi}$ の遊走刺 激活性は低下すると同時に，chemotaxis 抑制作用 の出現により炎症巣への過剒な好中球集積を抑制 し，好中球による組織障害への進展を防御してい る可能性がある。

また，肝内合成立進のため血中濃度が高くなっ た $\alpha_{1}-\mathrm{Pi}$ は, より強力な chemotaxis 抑制作用を 示し, その結果, 好中球の過㮃な血管外への遊走 を抑制するものと推察される。

$\alpha_{1}-\mathrm{Pi}$ 欠損症患者に沶いて, 感染刺激がみられ ないにもかかわらず, 肺胞内の好中球数が増加し ていることが報じられている11). 血中の低い $\alpha_{1}-\mathrm{Pi}$ 濃度は好中球に対する chemotaxis 抑制作用を低 下させると同時に遊走活性を逆に无進させると考 えられる。本症患者に括ける成績は, 筆者らの in vitro に打情成績から推定される $\alpha_{1}-\mathrm{Pi}$ の好 中球リクルーメントに対する調節機能が in vivo レ ベルでも作用しらる査証のひとつと考光られる。

このような $\alpha_{1}-\mathrm{Pi}$ の濃度依存性の好中球遊走能 に対する刺激性，抑制性の特異な二相性作用によ り，生:体内に打好中球リクルーメントならび
に炎症過程が修飾している可能性が考えられた。

稿を終えるに当り，ご指導ご校閲いただいた東 京女子医科大学第一内科滝沢敬夫教授に深謝いた します。また，研究や論文作成のご指導を賜った 第一内科永井厚志講師, 衛生学公衆衛生学教室石 原陽子講師に深く感謝いたします。

\section{文 献}

1) Zigmond, S.H.: Chemotactic response of neutrophils. Am. J. Respir. Cell. Mol. Biol. 1: 451453, 1989.

2) Shasby, M.: Antioxidant activity of some antiproteinases. Am. Rev. Respir. Dis. 131: 293294, 1985.

3) Smith, C.W., Hollers, J.C., Patrick, R.A. et al.: Motility and adhesiveness in human neutrophils: effects of chemotactic factors. J. Clin. Invest. 63: 221-229, 1979.

4) Goetzl, E. J.: Modulation of human neutrophil polymorphonuclear leucocyte migration by human plasma alphaglobulin inhibitors and syntheric estelase inhibitors. Immunology 29: 163174, 1975.

5) Falk, W., Goodwin, Jr., R.H., Leonard, E.J.: A 48 well-microchemotaxis assembly for rapid and accurate measurement of leukocyte migration. J. Immunol. Methods. 33: 239-247, 1980.

6) Zigmond, S.H., Hirsch, J.G.: Leukocyte locomotion and chemotaxis. New methods for evaluation and demonstration of a cell-derived chemotactic factor. J. Exp. Med. 137: 387-410, 1973.

7) Stockley, R.A., Shaw, J., Afford, S.C. et al.: Effect of alpha-1-proteinase inhibitor on neutrophil chemotaxis. Am. J. Respir. Cell Mol. Biol. 2: 163-170, 1990.

8) Banda, M.J., Rice, A.G., Griffin, G.L.: The inhibitory complex of $\alpha_{1}$ proteinase inhibitor and human leukocyte elastase is a neutrophil chemoattractant. J. Exp. Med. 167: 1608-1615, 1988.

9) Hakansson, L., Venge, P.: Partial characterization and identification of chemokinetic factors in serum. Scand. J. Immunol. 18: 531-537, 1983.

10) Wewers, M.D., Casolaro, M.A., Sellers, S.E. et al.:Replacement therapy for alpha 1-antitrypsin deficiency associated with emphysema., N. Engl. J. Med., 316: 1055-1062, 1987.

11) Morrison, H.M., Kramps, J.A., Burnett, D. et al.: Lung lavage fluid from patiets with $\alpha_{1}$ proteinase inhibitor deficiency or chronic obstructive bronchitis: anti-elastase function and cell profile. Clinical Science 72: 373-381, 1987. 